\title{
In-utero Diagnosis of Double Encephalocele - Imaging Features and Review of Literature
}

\author{
Chaitali Kantilal Shah ${ }^{1}$, Roland Y Lee ${ }^{2}$, Sunil Jeph ${ }^{3 *}$ \\ 1. Department of Radiology, Geisinger Medical Center, Danville, PA, USA \\ 2. Department of Internal Medicine, Penn State Health Milton S. Hershey Medical Center, Hershey, PA, USA \\ 3. Department of Radiology, Penn State Health Milton S. Hershey Medical Center, Hershey, PA, USA \\ * Correspondence: Sunil Jeph MD, Department of Radiology, Penn State Health Milton S. Hershey Medical Center, 200 Campus Dr \\ Suite 502, Hershey, PA 17033, USA \\ (入-3 suniljeph@gmail.com)
}

Radiology Case. 2021 Dec; 15(12):1-9 :: $\quad$ DOI: 10.3941/jrcr.v15i12.4230

\begin{abstract}
Encephalocele is protrusion of brain parenchyma through a defect in the cranium. It is classified into various types based on the defect location: sincipital (fronto-ethmoidal), basal (trans-sphenoidal, spheno-ethmoidal, trans-ethmoidal, and spheno-orbital), occipital and parietal. Double encephaloceles are very rare with only a handful of cases reported in the literature and most of these cases involved either occipital or sub-occipital region. All, except one, cases of double encephaloceles were diagnosed postnatally. We present a case of double encephalocele with parietal and occipital components diagnosed in utero. To the best of our knowledge, this is the first case of double encephalocele involving the parietal and occipital skull bones diagnosed in-utero.
\end{abstract}

\section{CASE REPORT}

\section{CASE REPORT}

An 18-year-old female, gravida 1, para 0, with gestational age of 22 weeks and 3 days was referred from an outside hospital with a diagnosis of posterior encephalocele of the fetus based on transabdominal ultrasound (US). The mother was a poor historian and suggested a non-specific family history of congenital diseases, which included maternal half-brother's son with congenital heart disease and some other family members with ankyloglossia. At our hospital, repeat transabdominal US revealed a large encephalocele from the left side of the fetal cranium and a small posterior encephalocele (Figure 1, In-utero US). The mother and the family were informed and explained about the poor functional prognosis if the baby survives. Obstetrics and gynecology were involved and had suggested to follow up with US and fetal magnetic resonance imaging (MRI). Fetal MRI revealed a large left parietal cranium defect and a small posterior cranial defect, with brain parenchyma protruding. (Figure $2 \& 3$, In-utero MRI). After delivery, the large parietal and small occipital encephaloceles were appreciated (Figure. 4). The baby was subsequently operated by pediatric neurosurgery and the encephaloceles were reduced. Figure 5 shows intra operative appearance of the occipital encephalocele before (Figure 5A) and after reduction (Figure 5B). Figure 6 show post-operative appearance status post reduction of both parietal and occipital encephaloceles.

After delivery, the baby was diagnosed with hypospadias, for which he underwent reconstructive urologic surgery. The baby had signs of global developmental delay and subsequent imaging revealed development of Ex-vacuo hydrocephalus with underlying encephalomalacia of the involved brain parenchyma (Figure 7, Post-natal MRI). Ventriculo-peritoneal shut was placed. The baby is now 2 years old and shows signs 
of global developmental delay and delayed milestones. The genetic testing revealed that the baby had a deletion of Xq28 involving the gene AFF2 (also known as FMR2, MRX2, FRAXE2).

\section{DISCUSSION}

\section{Etiology \& Demographics:}

Encephalocele is a congenital abnormality characterized by herniation of meninges, cerebrospinal fluid, and some parts of brain through a defect in the midline of cranial vault or base of skull. The etiology of encephaloceles is poorly understood. There are 3 major hypotheses to explain the morphogenetic events causing occipital encephaloceles. The first hypothesis suggests a mismatch between the growth of posterior fossa neural structures (which is normal) and base of skull (which is delayed), which leads to crowding of neural structures in the posterior fossa resulting in breech in overlying cutaneous and mesenchymal covering $[1,2]$. The second hypothesis suggests hydrocephalus causes deformation with entrapment, compression and displacement of posterior fossa structures. However, it was later concluded that the entrapment causes hydrocephalus [3]. The third hypothesis suggests encephalocele arise due to defect in neural tube closure. However, this was later refuted by the fact that the normal neural tube closure occurs early and encephalocele develops later [3].

Encephaloceles are rare with an incidence of $0.8-5$ per 10,000 live births worldwide [4]. Males and females have equal incidence [5]. Encephaloceles are usually solitary with occipital encephaloceles being more common in North America and Europe, while anterior encephaloceles being more common in Southeast Asia, Africa, Malaysia and Russia [6]. Double encephalocele is a very rare entity with few cases reported in the literature [4-10]. Just one case of parietal and occipital double encephalocele has been reported in literature.

The mechanism and the possible role of genetics are not known. Our patient had deletion of Xq28 involving the gene AFF2 (also known as FMR2, MRX2, FRAXE2). Although the precise function of AFF2 gene has not been explicitly determined, a previous case report found microdeletion of $\mathrm{Xq} 28$ involving only the AFF2 gene in two unrelated males with neurocognitive developmental delay. In the absence of additional significant genomic alterations, it was presumed that the loss of AFF2 gene in these two patients may be associated with their overlapping phenotypes [11]. Additionally, the baby's maternal family had a history of ankyloglossia and congenital heart disease.

\section{Clinical \& Imaging Findings:}

An encephalocele presents visibly as a skin-covered mass near the midline in the head. In anterior encephalocele, the presenting symptom can include nasal obstruction, nasal cleft, cerebrospinal fluid rhinorrhea, orbital displacement, telecanthus, and meningitis [12]. In posterior encephalocele, the most common presenting symptom is hydrocephalus followed by seizures [13]. A prenatal US is usually performed during early pregnancy between 11- and 14-weeks' gestation to evaluate the morphology of the fetus and to screen for a wide range of congenital anomalies, including central nervous system conditions such as neural tube defects [14]. By 13 weeks, US can differentiate a meningocele (without encephalic tissue herniation) from an encephalocele [15]. Computerized tomography (CT) can better visualize bone structures, while MRI is more accurate in visualizing soft tissues and can show herniation of brain tissue through the defect [16].

\section{Treatment \& Prognosis:}

The treatment of encephalocele is surgical, which consists of incision of the sac, amputation of the excess tissue to the level of the surrounding skull, closure of the dura, and closure of the skin [17]. In general, children with occipital encephalocele containing brain have poor prognoses. In addition to the content in the sac, the size of the lesion also affects the long-term prognoses. Larger lesions have been associated with poor results. In a previous study that followed 22 cases with occipital encephalocele up to 20 years, 16 lived without neurologic deficit, while 6 were mentally and/or physically disabled [18].

\section{Differential Diagnosis:}

The differential diagnoses include epidermoid cysts, hemangiomas, and cystic hygroma. US is often the initial screening diagnostic test, followed by MRI. Although CT may be used to delineate the bone anatomy, MRI is better for evaluating intracranial connection, defining the contents of an encephalocele, and planning for surgery.

\section{Epidermoid cysts}

Epidermoid cysts are slow-growing, painless masses that elevate the skin and often have a central punctum that represents the plugged orifice of the pilosebaceous follicle. On US, they have a round to oval structure, well-circumscribed, avascular mass located in subcutaneous tissue along with phenomena of dorsal acoustic amplification and lateral shadowing. On CT, they appear as a well-encapsulated mass of heterogeneous densities that represent a mixture of fat and keratin. An unruptured epidermoid cyst is demonstrated as a noninfiltrating, fluid density mass with a thin sclerotic wall. The wall can enhance on contrast-enhanced images. On MRI, they have slightly hypointense signal intensity on T1-weighted and intermediate to high signal on T2-weighted. Restricted diffusion is typical of epidermoid cysts [19]."

\section{Hemangiomas}

Infantile hemangiomas are the most common vascular tumor in childhood. On US, they are well-defined hypoechoic, heterogeneous echotexture with cystic sinusoidal spaces, and fast flow pattern. On MRI, typical features in the proliferating phase include dilated feeding vessels, variable intensity $\mathrm{T} 1$, hyperintense T2, and flow voids around and within the mass. In the involuted phase, decrease in the vessel size is seen [20].

\section{Cystic hygroma}

Cystic hygromas are congenital malformations of lymphatic system. On US, they appear as multicystic lesions with internal septations and no blood flow on color doppler ultrasonogram. On CT, they appear as a multicystic, homogeneous, non-invasive mass with low attenuation [21]. 


\section{TEACHING POINT}

Double encephaloceles, particularly involving parietal and occipital lobes, are a rare entity which can be diagnosed on an in-utero ultrasound with or without utilization of MRI examination.

\section{REFERENCES}

1. Marin-Padilla M. Notochordal-basichondrocranium relationships: abnormalities in experimental axial skeletal (Dysraphic) disorders. J Embryol Exp Morphol. 1979;53:1538. PMID: 536685

2. Marin-Padilla M. Study of the skull in human cranioschisis. Acta Anat (Basel). 1965;62(1):1-20. PMID: 5864445

3. Chapman PH, Swearingen B, Caviness VS. Subtorcular occipital encephaloceles. Anatomical considerations relevant to operative management. J Neurosurg. 1989;71(3):375-381. PMID: 2769389

4. Sharma S, Ojha BK, Chandra A, Singh SK, Srivastava C. Parietal and occipital encephalocele in same child: A rarest variety of double encephalocele. Eur J Paediatr Neurol. 2016;20(3):493-496. PMID: 26876766

5. Siffel C, Wong L-YC, Olney RS, Correa A. Survival of infants diagnosed with encephalocele in Atlanta, 1979-98. Paediatr Perinat Epidemiol. 2003;17(1):40-48. PMID: 12562471

6. Canaz H, Ayçiçek E, Akçetin MA, Akdemir O, Alata? I, Özdemir B. Supra- and infra-torcular double occipital encephalocele. Neurocirugia (Astur). 2015;26(1):43-47. PMID: 25307275

7. Menekse G, Celik H, Bayar MA. Giant parietal encephalocele with massive brain herniation and suboccipital encephalocele in a neonate: an unusual form of double encephalocele. World Neurosurg. 2017;98:867.e9-867.e11. PMID: 27867118

8. Ramdurg SR, Gubbi S, Odugoudar A, Kadeli V. A rare case of split pons with double encephalocoele, dermal sinus tract, and lipomeningomyelocele: a case report and review of literature. Childs Nerv Syst. 2014;30(1):173-176. PMID: 23811831

9. Singh DK, Singh N, Kumar P. Double suboccipital meningoencephalocele: a unique case report. Pediatr Neurosurg. 2012;48(5):331-332. PMID: 23838271

10. Sather MD, Livingston AD, Puccioni MJ, Thorell WE. Large supra- and infra-tentorial occipital encephalocele encompassing posterior sagittal sinus and torcular Herophili. Childs Nerv Syst. 2009;25(7):903-906. PMID: 19308424

11. Sahoo T, Theisen A, Marble M, Tervo R, Rosenfeld JA, Torchia BS, et al. Microdeletion of Xq28 involving the AFF2 (Fmr2) gene in two unrelated males with developmental delay.
Am J Med Genet A. 2011 Dec;155A(12):3110-5. PMID: 22065534

12. Thompson HM, Schlosser RJ, McCarty Walsh E, et al. Current management of congenital anterior cranial base encephaloceles. Int $\mathbf{J}$ Pediatr Otorhinolaryngol. PMID: 31931391

13. Rehman L, Farooq G, Bukhari I. Neurosurgical interventions for occipital encephalocele. Asian J Neurosurg. 2018;13(2):233-237. PMID: 29682014

14. Fong KW, Toi A, Salem S, et al. Detection of fetal structural abnormalities with US during early pregnancy. Radiographics. 2004;24(1):157-174. PMID: 14730044

15. Ong AGJ, Rolnik DL, Menezes M, Meagher S. Early diagnosis and differences in progression of fetal encephalocele. J Ultrasound Med. 2020;39(7):1435-1440. PMID: 31944319

16. Agladioglu K, Ardic FN, Tumkaya F, Bir F. Mri and ct imaging of an intrasphenoidal encephalocele: a case report. Pol J Radiol. 2014;79:360-362. PMID: 25324915

17. Hunt JA, Hobar PC. Common craniofacial anomalies: facial clefts and encephaloceles. Plast Reconstr Surg. 2003;112(2):606-615; quiz 616,722. PMID: 12900623

18. Date I, Yagyu Y, Asari S, Ohmoto T. Long-term outcome in surgically treated encephalocele. Surg Neurol. 1993;40(2):125-130. PMID: 8362349

19. Hoang VT, Trinh CT, Nguyen $\mathrm{CH}$, Chansomphou V, Chansomphou V, Tran TTT. Overview of epidermoid cyst. Eur J Radiol Open. 2019;6:291-301. PMID: 31516916

20. Abraham A, Job AM, Roga G. Approach to infantile hemangiomas. Indian J Dermatol. 2016 Apr;61(2):181-6. PMID: 27057018

21. Mirza B, Ijaz L, Saleem M, Sharif M, Sheikh A. Cystic hygroma: an overview. J Cutan Aesthet Surg. 2010 Sep;3(3):139-44. PMID: 21430825 


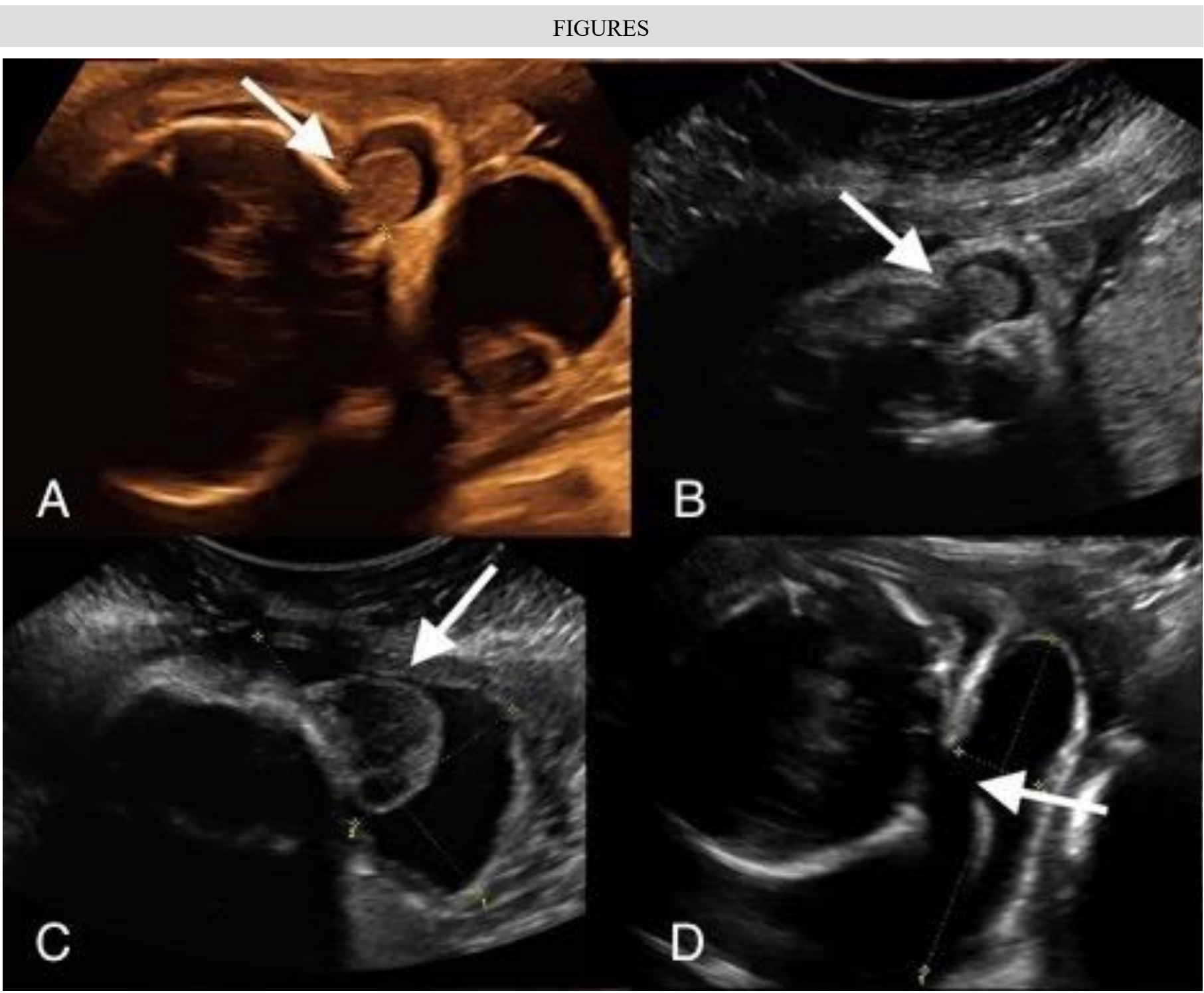

Figure 1: An in-utero male fetus with occipital and parietal encephalocele.

Findings: Intra uterine transabdominal fetal ultrasound showing occipital (A, B) and left parietal encephalocele (C, D).

Technique: Intra-uterine transabdominal fetal ultrasound showing oblique sagittal view (A, B) and oblique axial views (C, D) of the head. 


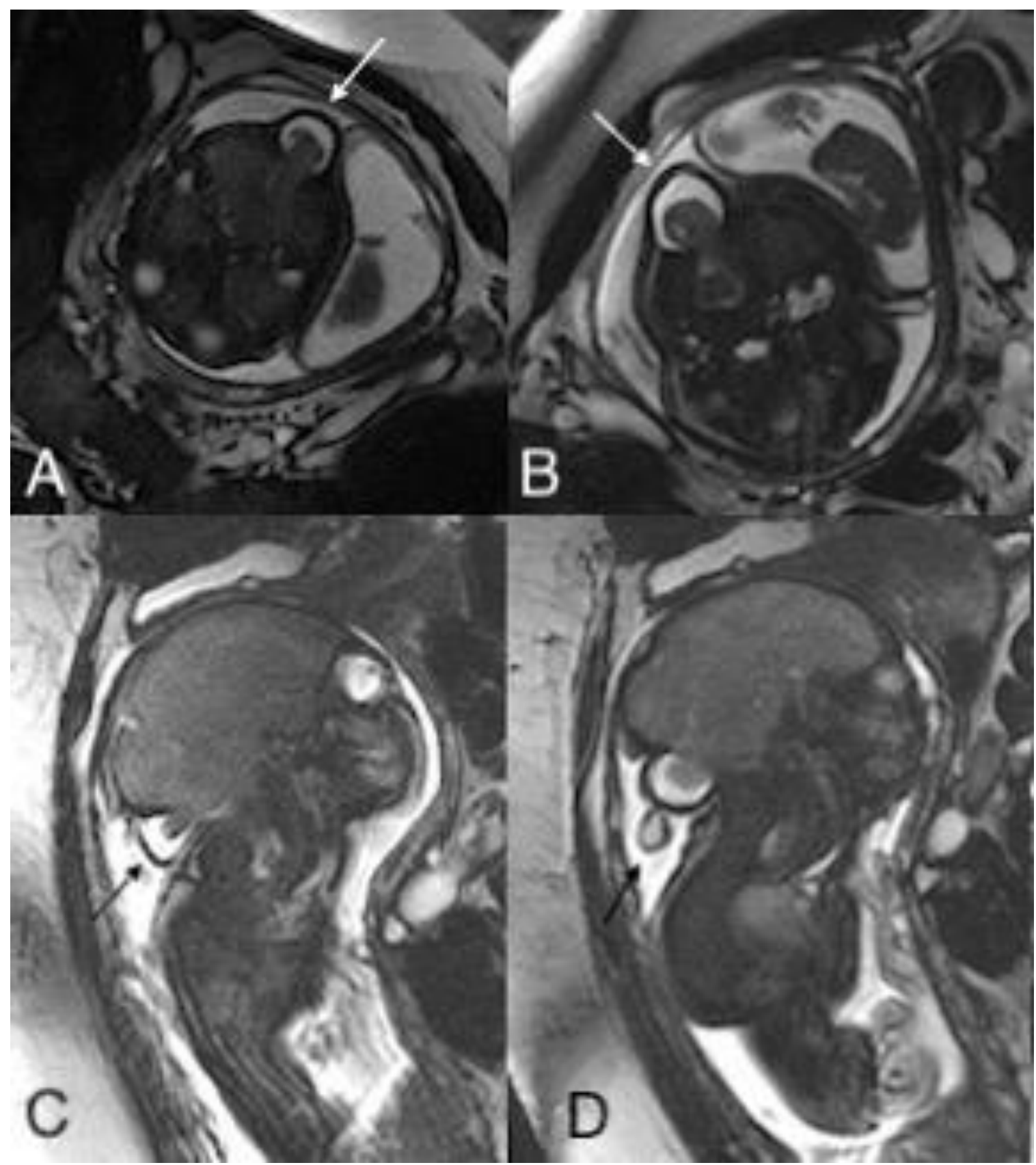

Figure 2: An in-utero male fetus with occipital and parietal encephalocele

Findings: Intra uterine fetal MRI showing occipital encephalocele with herniation of meninges and brain parenchyma through the bone defect in axial (A, B) and sagittal plane (C, D).

Technique: Intra-uterine fetal MRI with non-contrast T2 weighted images (1.5 Tesla, TR 4000, TE 90) in axial (A, B) and coronal (C, D) planes. 


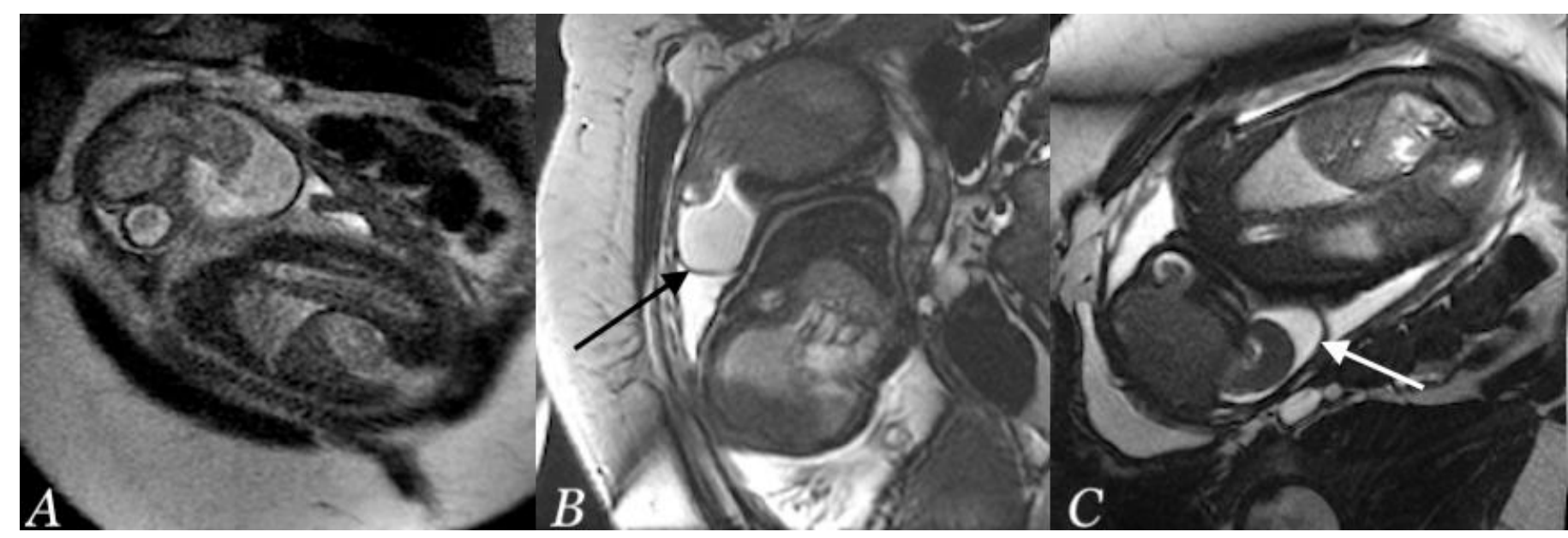

Figure 3: An in-utero male fetus with occipital and parietal encephalocele

Findings: Intra uterine fetal MRI showing left parietal encephalocele with herniation of meninges and brain parenchyma through the bone defect on coronal planes (A, B and C).

Technique: Intra-uterine fetal MRI with non-contrast T2 weighted images (1.5 Tesla, TR 4000, TE 90) in coronal plane (A, B and C).

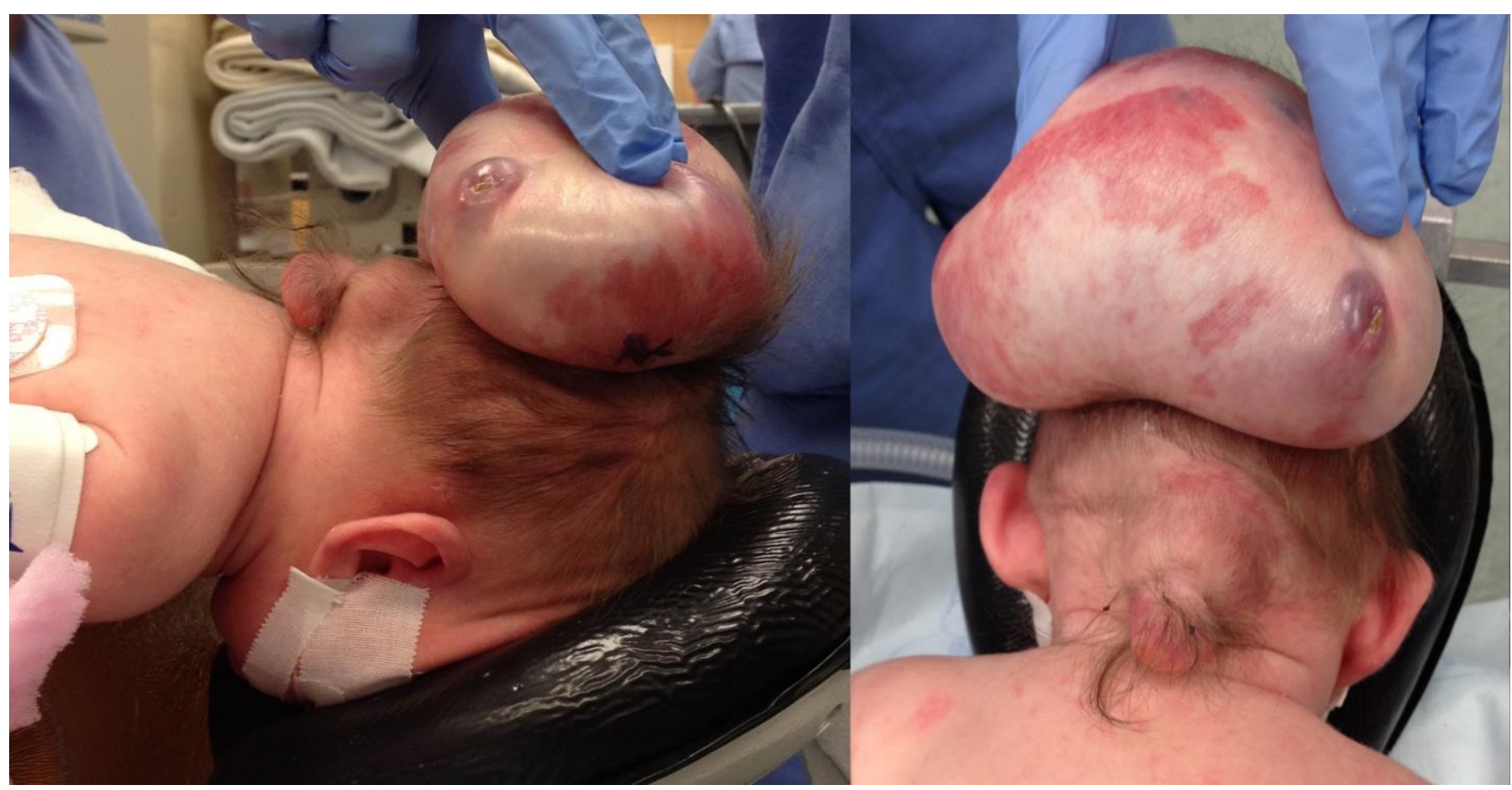

Figure 4: A newborn male infant with occipital and parietal encephalocele

Findings: Pre-operative photograph of the parietal (superiorly) and occipital (inferiorly) encephaloceles.

Technique: Pre-operative color photograph with the Patient positioned with face down displaying the encephaloceles. 


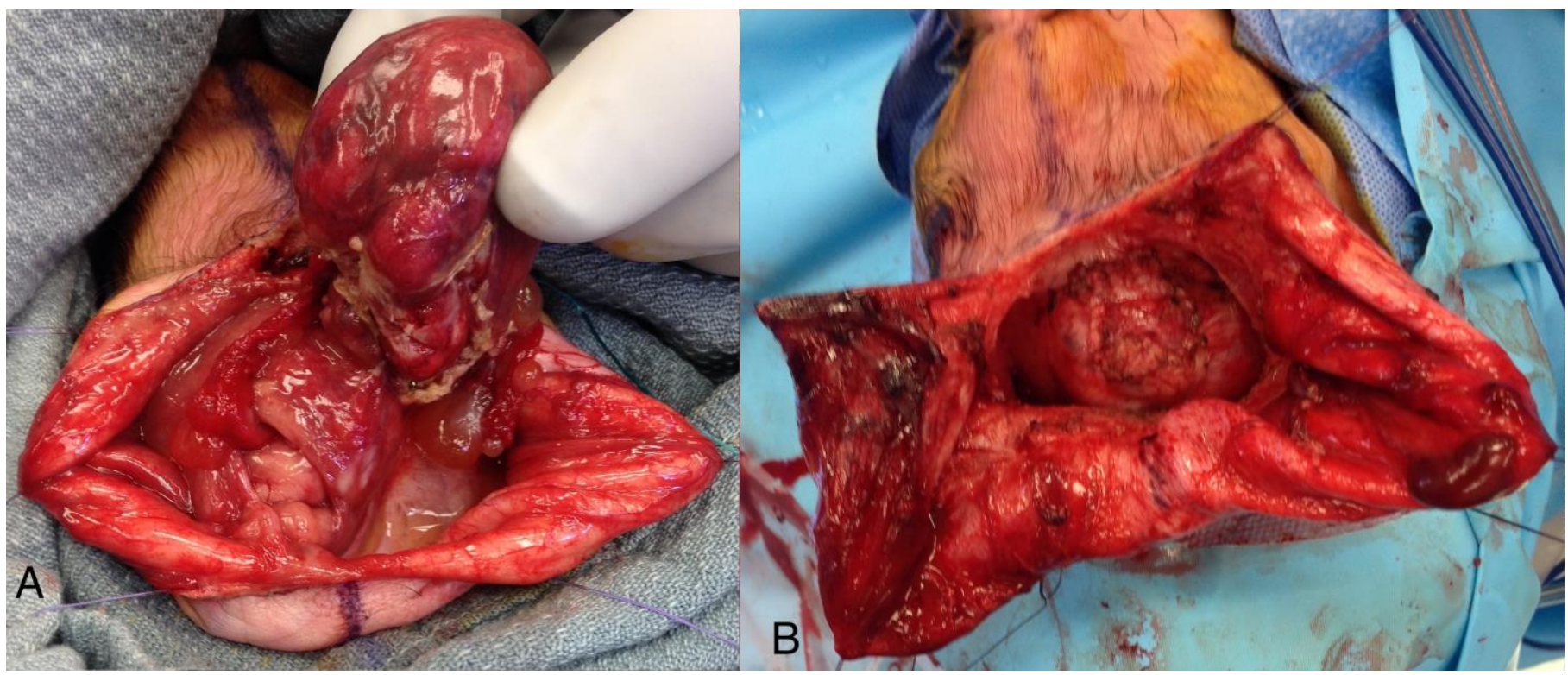

Figure 5: A newborn male infant with occipital and parietal encephalocele

Findings: Intra-operative photograph of occipital encephalocele before (A) and after (B) repair.

Technique: Intra-operative color photographs were acquired.

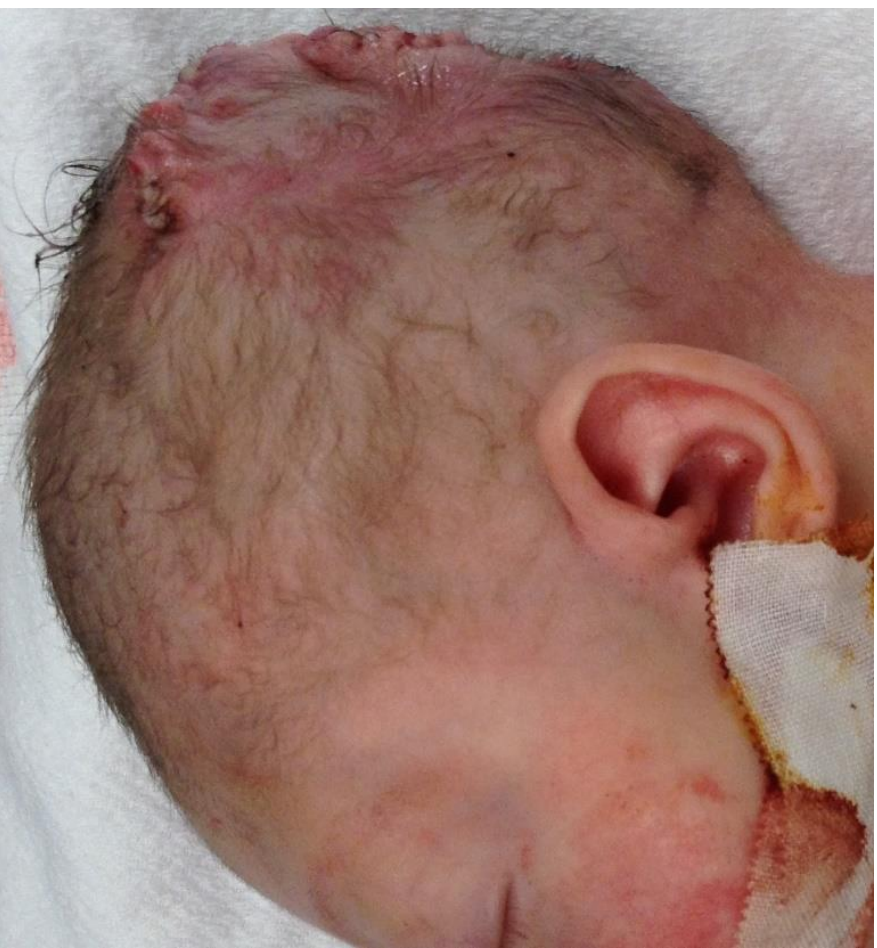

Figure 6 (left): A newborn male infant with repaired occipital and parietal encephalocele

Findings: Post-operative photograph showing repaired encephaloceles.

Technique: Post-operative color photograph was acquired showing the surgical site. 


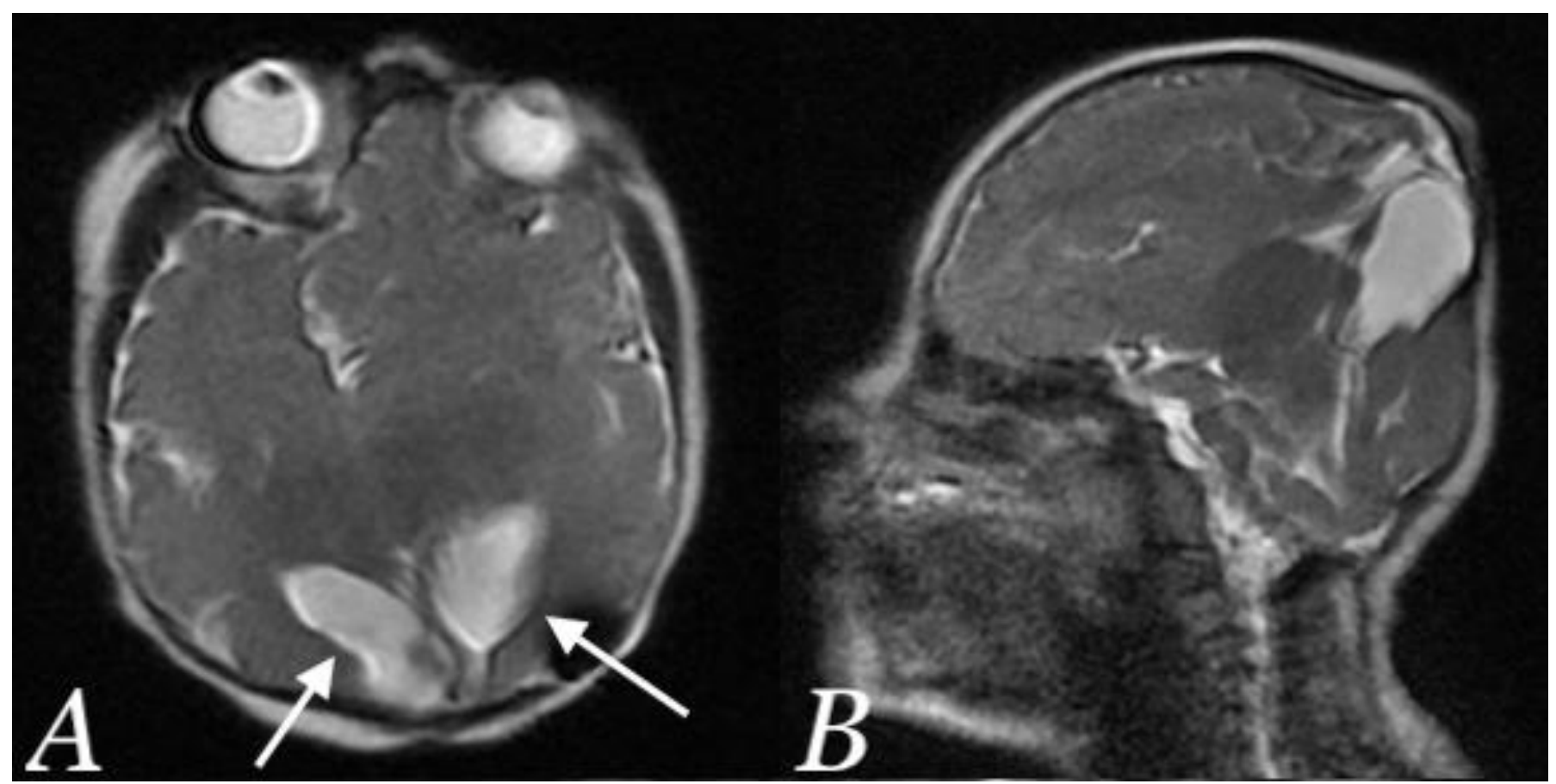

Figure 7: A newborn male infant with occipital and parietal encephalocele

Findings: Post-operative Brain MRI showing Ex-vacuo hydrocephalus involving occipital horns (white arrows) with underlying encephalomalacia in axial (A) and sagittal (B) plane.

Technique: Post-operative non-contrast T2 weighted brain MRI (1.5 Tesla, TR 4000, TE 90) in axial (A) and sagittal (B) plane.

\begin{tabular}{|l|l|}
\hline Etiology & $\begin{array}{l}\text { Uncertain, but proposed hypotheses include (1) mismatch between growth and posterior fossa neural } \\
\text { structures and base of skull, (2) hydrocephalus causes deformation with entrapment, compression, } \\
\text { and displacement of posterior fossa structures, (3) defect in neural tube closure }\end{array}$ \\
\hline Prevalence & 0.8 to 5 per 10,000 live births. \\
\hline Gender ratio & Male and female equally affected \\
\hline Age predilection & Congenital \\
\hline Risk factors & Unknown, but may be associated with genetic disorders. \\
\hline Treatment & Surgery \\
\hline Prognosis & $\begin{array}{l}\text { Depends on content and size of sac. Greater extent of herniated neural tissue and large sac are } \\
\text { associated with poor prognosis }\end{array}$ \\
\hline Findings on imaging & Herniation of brain parenchyma outside the cranium. \\
\hline
\end{tabular}

Table 1: Summary table of encephalocele. 


\begin{tabular}{|l|l|l|l|}
\hline Imaging Modality & US & CT & MRI \\
\hline Cystic hygroma & $\begin{array}{l}\text { Nuchal cyst with or } \\
\text { without septations. No } \\
\text { cranial defect or extension } \\
\text { of cranial contents noted. }\end{array}$ & $\begin{array}{l}\text { Hypoattenuating ill-defined } \\
\text { cystic mass }\end{array}$ & $\begin{array}{l}\text { Predominantly T2 hyper-intense. T1 } \\
\text { dark unless there is hemorrhage. No } \\
\text { enhancement except occasional faint rim } \\
\text { of peripheral enhancement. }\end{array}$ \\
\hline $\begin{array}{l}\text { Dermoid and } \\
\text { epidermoid cysts }\end{array}$ & $\begin{array}{l}\text { Round to oval structure, } \\
\text { well-circumscribed, } \\
\text { avascular mass located in } \\
\text { subcutaneous tissue along } \\
\text { with phenomena of dorsal } \\
\text { acoustic amplification and } \\
\text { lateral shadowing }\end{array}$ & $\begin{array}{l}\text { A well-encapsulated mass of } \\
\text { heterogeneous densities that } \\
\text { represent a mixture of fat and } \\
\text { keratin. An unruptured } \\
\text { epidermoid cyst is } \\
\text { demonstrated as a } \\
\text { noninfiltrating, fluid density } \\
\text { mass with a thin sclerotic } \\
\text { wall. }\end{array}$ & $\begin{array}{l}\text { Depends on the contents of the cyst and } \\
\text { may range from pure fluid signal } \\
\text { intensity (hypointense on T1-weighted } \\
\text { images, hyperintense on T2-weighted } \\
\text { images) in an epidermoid cyst to a more } \\
\text { complex signal intensity (hyperintense } \\
\text { on T1-weighted images, hypointense on } \\
\text { T2-weighted images) in a dermoid cyst. }\end{array}$ \\
& $\begin{array}{l}\text { Echogenic well-defined } \\
\text { mass that may exhibit } \\
\text { prominent internal } \\
\text { vascularity on color } \\
\text { Doppler. }\end{array}$ & $\begin{array}{l}\text { Lobulated mass with the } \\
\text { same density to the adjacent } \\
\text { muscles and exhibiting a } \\
\text { vivid and homogeneous } \\
\text { contrast enhancement. }\end{array}$ & $\begin{array}{l}\text { T1 intermediate signal, T2 hyperintense, } \\
\text { although small areas of hypo intensity } \\
\text { may be present (flow-voids, fibrous } \\
\text { tissue, or calcification). Homogeneous } \\
\text { post contrast enhancement. }\end{array}$ \\
\hline Hemangiomas
\end{tabular}

Table 2: Differential diagnosis table for encephalocele.

\section{ABBREVIATIONS}

$\mathrm{CT}=$ Computerized tomography

MRI = Magnetic Resonance Imaging

US = Ultrasonography

\section{KEYWORDS}

encephalocele; in-utero; MRI; fetal; cranium; double encephalocele

\section{ACKNOWLEDGEMENTS}

Anne P. Dunne MD, Program Director, Radiology, Geisinger Medical Center, Danville, PA, USA and Amir Kershenovich MD, Director, Pediatric Neurosurgery, Geisinger Medical Center, Danville, PA, USA

\section{Online access}

This publication is online available at: www.radiologycases.com/index.php/radiologycases/article/view/4230

\section{Peer discussion}

Discuss this manuscript in our protected discussion forum at www.radiolopolis.com/forums/JRCR

\section{Interactivity}

This publication is available as an interactive article with scroll, window/level, magnify and more features.

Available online at www.RadiologyCases.com

Published by EduRad

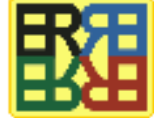

www.EduRad.org 